\title{
The Formation of a Post-Peronist GENERATION: Intellectuals and Politics in Argentina through the Lens of Contorno (1953-1959)
}

\section{INTRODUCTION}

A significant segment of the Argentine intelligentsia experienced the Revolution of September 1955, which overthrew General Juan Domingo Perón, as a moment of liberation. ${ }^{1}$ With some exceptions, such as Arturo Jauretche and Raúl Scalabrini Ortiz among others, the cultural politics of Peronism had not managed to gain many followers in the course of its ten-year experiment. During the two consecutive Perón governments (1946-1955) the often implicit, and occasionally explicit, opposition between intellectuals and Peronism only intensified. ${ }^{2}$ I contend that an analysis of this opposition is indispensable for understanding the redrawing of crucial definitions within the intellectual field at that time. Due to its profound social and cultural impact, the experience of Peronism compelled Argentine intellectuals, whether or not it was their original intention, to enter the political arena, not so much because their interests shifted from culture to poli-

A preliminary version of this article was presented on the panel "The Politics of Nationalisn in Twenticth-Century Argentina," at the LASA Congress 2006 in San Juan, Puerto Rico. Many individuals have provided valuable comments on this work. In particular, I would like to thank Professors Daniel James, Alejandro Mejías-López, Patrick Dove, and Jeffrey Gould-who taught a seminar in which this project was born-all from Indiana University. Professor Barbara Weinstein, of New York University, gave me powerful comments and suggestions to make this article interesting for a non-Argentine audience. I am also in debt to Rose Shapiro and Gina Robinson, both of whom did a great job editing different parts of this article, and to Lynn Di Pietro, who carcfully translated the quotations from Spanish. Finally, I wish to thank the two anonymous reviewers for The Americas for their suggestions and criticisms.

1. I take this expression from a famous article by Tulio Halperin Donghi in an issue that Sur devoted to "national reconstruction." Sec Tulio H. Donghi, "La historiografia argentina en la hora de la libertad," Sur, 237 (1955), pp. 114-121.

2. On the 1973 celebration of Perón's return to power nearly two decades after his fall, historian Félix Luna recalled this opposition as a historical error. "Between 1945 and 1955," Luna wrote, "Peronism also left a defined cultural mark. But it was a mark that could not transcend itself for the simple reason that the culture professionals were on the other side of the official frontier. It was not a question of assigning blame. There was blame on both sides. On the official side, awkwardness and pretensions of imposing a tedious uniformity; on the side of the intelligentsia, excessive sensitivity, rejection of the 'popular' and nearsightedness in the face of the process they were living through." Félix Luna, “La cultura nacional," Panorama 321 (June 1973), p. 34. 
tics, but rather because they came to conceive the cultural world as political. This blurring of intellectual boundaries obliged many of the protagonists of the cultural world to descend from the purity of ideas to the dark reality of politics. ${ }^{3}$

This pressure for figures in the cultural world to confront and assimilate "reality," the moral and intellectual obligation to "get their hands dirty" in the mud of the world, was a general feature of the intellectual scene of 1950's Argentina, but it was especially evident in the group of young people who coalesced around the journal Contorno. While this journal stands apart in many ways, it was nevertheless an expression of an emergent discourse that can be detected in many journals of the time. In the history of Argentine culture, the 1950s were unusual in witnessing the proliferation of significant journals. Contorno-the culmination of a path initiated in Verbum, continued in Centro, and solidified in a third journal, Las Ciento $y$ Una ${ }^{4}$-would go on to become one of the most famous of this era. Many other journals were published during this period, some of them quite important; noteworthy examples include Sur, Gaceta Literaria, Capricornio, Letra y Linea, Buenos Aires Literaria, the Uruguayan Marcha, and Ciudad (which was allied with Contorno in its revisionist commitment). ${ }^{5}$ In the face of such an explosion of journals, why, then, does Contorno stand out, and why is it so important in an analysis of the links between intellectual and political concerns?

If we emphasize its later influence rather than its contemporary repercussions, it is clear that Contorno showcased the talents of a very important cohort; later works by Contorno contributors David Viñas, Juan José Sebreli, Oscar Masotta, and León Rozitchner would play a significant role in Argentina's intellectual sphere. Although the passage of time and the scholarly attention that has been lavished on it has helped to make Contorno a nearly mythical journal, what ultimately gives it a place within the Argentine history of ideas in the twentieth century is its ability to express the context, the contorno, of what was happening in the cultural

3. I am not implying that there was no political involvement on the part of intellectuals before Peronism. For example, during much of the nineteenth century, many intellectuals were known to be politically committed and many politicians considered themselves intellectuals. Nonetheless, towards the 1930s there was a certain separation between the spheres of thought and action, cspecially in the intellectual world. And it is precisely in opposition to the political disengagement of the intellectual generation of the 1930s, that in the 1950s (and as a result of Peron's movement), cultural activity couldn't be considered in any other way than as essentially political. Making culture would be, from then on, making politics.

4. Las Ciento y Una appeared in June of 1953 , five months before Contorno's first issue. In fact, this journal's first and only issue may be considered Contorno's preface.

5. For a comparative analysis of the two above-mentioned journals and Contorno, see María Luisa Bastos, "Contorno, Ciudad, Gaceta Literaria: tres enfoques de una realidad," Hispamérica 4-5 (1973). For an analysis of the journal Marcha, see Rubén Cotelo, "Marcha y la Generación del 45," in Saúl Sosnowski (ed.), La cultura de un siglo. América latina en sus revistas (Buenos Aires: Alianza, 1999). For an analysis of Sur, see John King, Sur: A Study of the Argentine Literary Journal and Its Role in the Development of a Culture, 1931-1970 (Cambridge: Cambridge University Press, 1986). 
and political world, and therefore to provide a way to understand its central issues. ${ }^{6}$ This ability makes Contorno a privileged site for understanding the transformation of the relationship between intellectuals and politics.

Most studies of Contorno emphasize its status as a literary journal by underscoring either its literary revisionism or its cultural project, suggesting at the same time that politics did not enter the Contorno scene until late in its run. Carlos Mangone and Jorge Warley, for example, maintain that only in Contorno's final issues did the "eruption of the political" take place; similarly, William Katra identifies a "shift in focus from literary to social and political concerns, beginning with their journal's fifth issue in 1956."8 Years later, Carlos Altamirano reiterated a similar diagnosis when he affirmed that "even the issue [of Contorno] dedicated to the Peronist question bore the hallmark of a literary magazine." "When Beatriz Sarlo emphasized the importance for Contorno of "los cruces, los encuentros, las tramas" (encounters, crossroads, and interweavings), she pointed out that "politics is reflected in literature and literature acts as a metaphor for politics." 10 Nonetheless, Sarlo does not develop the analysis implicit in this statement, omitting matters such as how and under what circumstances the relationship between politics and literature is redefined in the Contorno experience. Along the lines of Sarlo's argument, and in contrast to the other aforementioned works, I suggest that a political dimension is present from Contorno's very inception, even in the more ostensibly literary issues.

In contrast to the existing studies of the journal, my aim is to read Contorno's literary preferences and positions as political preferences and positions and, by doing so, I analyze the ongoing redefinition during the 1950 s of the relationship between art and politics, which is key to understanding the subsequent decades. Revisiting the cultural and political atmosphere of the 1950 s through rereading Contorno and analyzing the debates found in it allows us to understand when and how a segment of the Argentine intelligentsia began to consider the aesthetic act as essentially political. During the 1920 s art and politics were seen almost as dis-

6. Referring to the origin of the journal's name, David Viñas affirmed that "Perhaps I have myself to blame for this, but evidently what we wanted to signal out was what [was] happening around us." Interview with David Viñas, "Nosotros y ellos. David Viñas habla sobre Contorno," Punto de Vista 13 (November 1981), p. 11.

7. Carlos Mangone and Jorge Warley, "La modernización de la crítica. La revista Contorno," Historia de la Literatura Argentina 113 (1983), p. 452.

8. William Katra, Contorno: Literary Engagement in Post-Peronist Argentina (London and Toronto: Associated University Presses, 1988), p. 120.

9. Carlos Altamirano, "Estudio preliminar. ¿Qué hacer con las masas?," in Beatriz Sarlo (ed.), La batalla de las ideas 1943-1973 (Buenos Aires: Ariel, 2001 ), p. 27.

10. Beatriz Sarlo, "Los dos ojos de Contorno," Revista Iberoamericana 125 (1983), p. 805. Although my work is in some way based on this assertion of Sarlo's, I should note that she carried out an analysis that differs from mine in that, in her reading, she grants history, not politics, a leading role. According to her, "both the role of the novelist and the place of literature remain defined in Contorno by history." Ibid. 
tinct spheres, while towards the end of the 1960s the two were seen as indistinguishable. In between was the key period of the 1950s, a turning point whose clearest expression was Contorno.

\section{CONTORNO IN ITS SURROUNDINGS}

Contorno began with a sort of manifesto, signed by Juan José Sebreli, called "Los martinfierristas: su tiempo y el nuestro." 11 The article sharply delineated what Contorno did not want to be: Martinfierristas. The journal Martin Fierro, published from 1924 to 1927 , had been a vanguard bimonthly publication whose main purpose was to renew Argentine literature by incorporating into it some of the latest European cultural trends. Martin Fierro had two immediate precedents: the journals Prisma and Proa (primera época), both founded by Jorge Luis Borges. Borges's own work was also a strong presence in the pages of Martin Fierro, and he brought to the journal the Ultraist aesthetic he had experienced firsthand during his recent stay in Spain. ${ }^{12}$ Besides Borges, Oliverio Girondo, Macedonio Fernández, Ricardo Güiraldes, Leopoldo Marechal, the brothers Enrique and Raúl González Tuñón, and Eduardo Mallea (who later became one of Contorno's principal obsessions), among others, collaborated on the journal.

The group associated with Contorno was most ashamed of (and anxious to correct) the omissions of the Martinfierristas, what the Contornistas believed their predecessors had not accomplished. They saw the Martinfierristas as content with (or ignorant of) reality, dazed by an anecdotal and melodramatic construction of the world, as shallow inheritors of a past that, ultimately, they revered, and as lost in the youthful and irresponsible game of rebelling without purpose. The Martinfierristas would be known, according to Contorno, for what they failed to do and what they failed to say: "We feel that we are somehow responsible for what intellectual and spiritual figures never accomplished. We feel even more responsible for what they didn't do than for what they did." 13 Contorno thus defined its own role

11. Contorno appeared for the first time towards the end of the year 1953, under the direction of Ismael Viñas. Its double number $9-10$, in April of 1959 , brought the journal to a close. By that time (starting with numbers 5-6), its direction had already passed to the hands of a board. The board of directors during the double numbers 5-6 and 7-8 was formed by Ismael and David Viñas, Noé Jitrik, Adelaida Gigli, Ramón Alcalde, and León Rozitchner. By the numbers 9 10, without Noé Jitrik, Adolfo Prieto joined the board. Also collaborating in Contorno: were Oscar Masotta, Juan José Sebreli, Carlos Correas, Tulio Halperín Donghi, Francisco J. Solero, Rodolfo Kush, Regina Gibaja, Héctor Miguel Angeli, Ramón Elorde, Fernando Kiernan, Jorge Arrow, Aldo Prior, Ana Goutman, Valentín Fernando, Orlando Suevo, Pagés Larraya, Víctor Aseef, Guillermo Steffen, Rodolfo Pandolfi, Jorge Curi, Julio Gargano, Osiris Troiani, and Ernesto Verón Thirion. The project Contorno involved two editions of the so-called Cuadernos de Contorno. The first Cuaderno was published in July of 1957 and the second in February of 1958.

12. Ultraism was an avant-garde literary movement that took shape in Spain around 1918 and whose creed defied that of modernismo, among whose major figures were, for instance, Rubén Darío and Lcopoldo Lugones.

13. Ismacl Viñas, "La traición de los hombres honestos," Contorno 1 (1953), p. 3. 
in the intellectual and cultural context of the time; they aspired to be the generation responsible not only for their own achievements but also for revealing the failures of those preceding them.

For this new generation, responsibility meant engagement. Existentialism of the French variety, especially as expressed by Jean-Paul Sartre, also formed part of Contorno's context. ${ }^{14}$ Even though not all of their members read those authors, the journal was clearly steeped in an existentialist mood. Universal subjects hardly concerned them; only the individual mattered, man in his context. Imbued with this philosophy, Contorno was published in the decade that heard the most vivid echoes of Sartre's Les Temps modernes. ${ }^{15}$ Almost ten years before Contorno's first publication in Argentina, the Sartrean journal rejected art for art's sake and advocated engaging with the immediate situation, moving from audience to actor, abandoning abstract and irrelevant art, and turning thoughts and ideas into committed and incisive action. Contorno inherited from Les Temps modernes this vocation for transforming their world. ${ }^{16}$

Among the journals mentioned above, Sur was Contorno's main rival. For the Contornistas, Sur was much more than the heir to the vanguard and Europeanizing vocation of Martin Fierro; it was the most distinguished organ of Argentine cultural liberalism, the intellectual voice of the Pampeana oligarchy, ${ }^{17}$ the "colonialist anti-Peronism." 18 Founded in 1931 by Victoria Ocampo, by 1950 Sur had great stature within the Argentine and American cultural worlds. Meticulous translations of Huxley, Jung, Joyce, Camus, and Sartre (among

14. Sebreli would later refer to this influence over some of the members of Contorne by saying: "We identified ourselves with our favorite heroes, the Sartre clan. Masotta argued with me about Merleau-Ponty and Correa argued with me about Genet, but there was no dispute over Simone de Beauvoir, and the three of us, of course, identified ourselves with Sartre." Juan J. Sebreli, “La operación Correas," in El Ojo Mocho 16 (Sunmer 2001/2), Dossier. Further, Lcón Rozitchner was familiar with the work of Mearleau-Ponty. It can be concluded that, notwithstanding the specific influences, the journal in general breathed an existentialist atmosphere. For instance, in the short story "El revólver," dedicated to Sebreli, Correas wrote: "And after that I won't exist. How rotten! I will be in the way on both sides. I have no place. I would like to vomit. To escape [it all] through the mouth. I would need to unload everything sonicplace. However, I did get something out of this, fear." Contorno 3 (1954), p. 12. This fragment is clearly inspired by the Antoine Roquentin of La Nausée.

15. Other publications, for instance Sur, reproduced articles from Les Temps modernes long before Contorno's appearance. However, as 1 point out, it would not be correct to attribute to Sur an existentialist intellectual bent.

16. "This influence was explicitly acknowledged by some members of Contorno. See, for instance, David Viñas, "Les temps modernes et nous," Les Temps modernes (1981) 420-421.

17. Tulio Halperín Donghi has affirmed, in his analysis of the Irazusta family, that the Argentine oligarchy was, at least in its inception in the nineteenth century, less a social or political elite than a cultural one. Into the twentieth century, there was no doubt that the oligarchy had already organized politically and could be considered a social sector. However, one must not lose sight of the fact that the intellectual concerns and the place high culture had in this sector werc from the beginning what identified it as a class. Sce Tulio H. Donghi, El revisionismo bistórico argentino (México: Siglo XXI, 1970).

18. This expression belongs to Oscar Masotta. See "Sur o el antiperonismo colonialista," Contorno 7-8 (1956), p. 39. Contorno clearly did not represent a colonialist project; nevertheless, it turns out to be quite difficult to separate it from a certain Europeanist cultural dependence. 
others) brought prestige to both the journal and its local collaborators. ${ }^{19}$ Politically speaking, from 1945 on, Sur became for Peronism what Sarmiento, Echeverría, and Mármol had been for Rosism. ${ }^{20}$ Nevertheless, although the members of Sur were completely aware both of their own political position and that of their adversaries, this did not translate into a new conception of the literary or aesthetic act as essentially political. As I shall argue below, for these writers and thinkers literature did not have to be at the service of any other cause but the literary; engaged literature was not a goal to be pursued but, on the contrary, a practice to avoid.

Civilization and barbarism, the famous slogan appearing in Facundo Sarmiento's diatribe against Rosas, was picked up by Sur against Perón-now cast as a contemporary tyrant. It is in this context that Contorno sought to adopt a delicate position: away from Sur's anti-Peronism but no closer to official politics. They wanted simultaneously to be anti-Peronists-because they clearly wanted to distance themselves from its narrow-minded and corrupt cultural world-and antianti-Peronists-because they repudiated the gorilismo ${ }^{21}$ that inspired Sur. On the one hand, Contorno and Sur certainly differed from each other in the way that they were anti-Peronists, but they also differed in the spaces that they occupied with respect to Peronism. The Sur group predated Peronism and was regarded as the intellectual expression of the social sector that Peronism singled out as the enemy of the patria, that is, the landowning oligarchy, economically liberal and politically conservative. Sur found in Peronism a class enemy; therefore, their opposition was expressed chiefly in the wish to return the nation to its pre-Peronist condition. The Contorno group, instead, emerged after-and, to a certain point, as a result of - the onset of the Peronist era. They expressed an intellectual, non-orthodox leftist position. With a more limited public than Sur and because of its appearance towards the end of 1953 (in the declining years of the first Peronist period), the journal never became one of Perón's main worries. Their intellectual aspiration was to express the interests of the same class Peronism allegedly represented (the working class), and their opposition to Peronism was linked to their ambition to overcome Peronism by moving forward, toward a government that differentiated itself from both the Peronist state and the liberal-oligarchic state that Peronism had replaced.

19. Daughter of Manuel Ocampo and Ramona Aguirre (both were members of two of the most traditional families of Argentina), Victoria Ocampo was unquestionably one of the main characters of the Argentine cultural world. Ocampo was an intellectual, a writer, a liberal, a feminist, and an anti-Peronist who founded and promoted a cultural space without precedent in Buenos Aires, becoming the hostess and editor of the major intellectuals of Europe. Many of the Argentine writers who gathered around her journal would later become targets of the Contornistas' incisive darts, among them, Mallea, Borges, Bioy Casares, and Victoria Ocampo herself.

20. The term "Rosism" refers to the Juan Manuel de Rosas Buenos Aires government (1835-1852), which its detractors characterized as a bloody and cruel dictatorship.

21. This term is a slur referring to the anti-Peronists. 
During the $1950 \mathrm{~s}$, although with some exception, to be an intellectual was to be anti-Peronist. ${ }^{22}$ United in the face of this common enemy, the intellectuals of the time nevertheless felt compelled to distinguish among various types of anti-Peronism. Thus Contorno attacked not only Sur's liberal anti-Peronism but also the Communist Party's (PC) brand of leftist anti-Peronism. Unlike Sur's liberal antiPeronism, Contorno and the PC did make a distinction between the Peronist masses and their leader, though each of them analyzed the relationship in a different light. Contorno and the PC shared the same Marxist vocabulary, but those associated with the journal utterly rejected both the orthodox and determinist views of the party, which they believed precluded the possibility of social change by ultimately placing such change in the hands of dehumanizing objective forces.

In sum, the goals consciously pursued by the members of Contorno were to distinguish themselves from the Martinfierrista movement, to incorporate the existentialist philosophy of engagement, to review the problems related to "national being," to engage in debate with the journal Sur, to question the literary canon, and to distance themselves from the anti-Peronism of both the liberals and the PC. In pursuing these goals, Contorno simultaneously participated-largely unconsciously -in a profound transformation of the relationship between intellectuals and politics, and the journal became the clearest expression of that transformation. This analysis of how the Contornistas carried out these objectives allows us to reconstruct some of the most important features of this transformation, which was destined to have a profound impact in Argentina over the next two decades.

\section{Aesthetics and Politics}

Contorno's reading of Martinfierrismo functioned as both a critique and a means to differentiate the two groups, perhaps because they had much in common, especially their youth. The Contornistas shared with the Martinfierristas a tendency to revisit the past and to reject acclaimed writers; they also resented their fathers and refused to inherit their legacy. As in Martin Fierro in the 1920s, Contorno sensed

22. When I interviewed him, Sebreli confirmed the following characterization: "Peronism was anti-intellectual, explicitly anti-intellectual, anti-cultural, or in the best of scenarios, indifferent." (Interview by author. Juan J. Sebreli, 4 August 2005.) Rozitchner, on the other hand, made this judgment much broader: for him, Peronism meant, in addition, "an cnormous repression of human relations." (Interview by author. Lcón Rozitchner, 2 August 2005.) However, it is commonly heard that within Contorno there was a subgroup formed by Sebreli, Correas and Masotta who leaned toward Peronism. See, for instance, Mangone and Warley, "La modernización de la crítica." In this study I seck to inquire about this leaning. Regarding the disagreement with the Peronist anti-intellectualist cultural politics, during the Peronist government all of Contorno was anti-Peronist. Likewise, the collaboration of this subgroup with the journal Sur must not be considered as detrimental to the rivalry held between them. Sebreli settled the paradox of collaborating with both publications when he affirmed that "the 'left' of Sur will be the 'right' of Contorno." Juan J. Sebreli, "Testimonio," Historia de la Literatura Argentina 113 (1983), p. 441. However, in all that concerns the rejection of the prevailing antinationalist liberal ideology in Sur, all Contorno members were anti-Sur. 
that the time for rebellion had arrived. With so many shared attitudes, Contorno's need to distinguish itself from the Martinfierristas demonstrates both denunciation and fear: on the one hand, they denounced intellectual posturing, and, on the other, they feared that their own position might be confused with that which they were denouncing. ${ }^{23}$

In order to alleviate this anxiety, Contorno's young devotees criticized the very idea of youth, regarding it as a bourgeois dream, while the Martinfierristas believed that the mere fact of being young entitled them to take shots at the past, to defy tradition-to commit, in Sebreli's words, a "cultural parricide." Contorno defined youth as "an artificial age-a mirror image of the bourgeois consciousness." ${ }^{24}$ In their own words, the Martinfierristas were young people who

believed themselves entitled to life because of their youth; in much the same way as the 'elite' believe they have the right to rule because they are the most capable. The cult of Youth-seen as a secret society formed to blow up the world of the older generation-is both a subjective designation and a social reality: like all human events it is bound to a concrete situation. ${ }^{25}$

In the Marxist mode, then, the Contornistas inferred the class consciousness of the Martinfierristas from the historical position that the latter occupied. Below I will explain how they resolved the problem of belonging to the bourgeoisie while disowning bourgeois class consciousness.

Contornistas tended to be young people with a non-bourgeois class consciousness; mature, engaged, and responsible, they were, ultimately, young people without youth. They described themselves as "a generation who, the day after sex, wake up to a sad somber dawn; in which happiness has turned into boredom; and alcohol has left them in a drunken haze, feeling tired, nauseous, heavy headed, and with a sour taste in their mouths."26 For these young people, the generation of 1924-the Martinfierrista generation-lived large, squandered the savings of decades of spiritual asceticism, and began a voyage not because they were interested in arriving at a specific destination, but for the mere pleasure of traveling.

The lack of engagement, the empty aesthetics, and the puerile and fantastic art that, according to Contorno, characterized the generation that preceded them

23. This fear can be perceived in several articles. For instance, in issue no. $5-6$, the lead Editorial responded to $a$ comment made in the journal Marcha: "That opinion [appearing in Marcha, which had accused Contorno of alternating "praising and damning"] concerned us a little bit. It made us afraid of appearing as low lives or mischievous kids." Editorial, "Terrorismo y complicidad," Contorno 5-6 (1955), p. 1.

24. Juan J. Sebreli, "Los martinfierristas: su tiempo y el nuestro," Contorno l (1953), p. 1.

25. Ibid.

26. Ibid. 
might be summed up in one general accusation: their predecessors lacked political commitment. These "honest men," as Ismael Viñas mockingly called themtoday "illustrious shadows" in the pages of Sur-enjoyed the luxury of annihilating the spiritual legacy of the $1890 \mathrm{~s}^{27}$ in order to replace it with a literature "without dirt, hunger, and sweat," a literature divorced from reality, an apolitical literature. Adolfo Prieto was to go even further. He would accuse them of being "great literary figures with no literature," 28 accusations that echoed those of Sebreli and Ismael Viñas. The characters drawn by these great authors "live, speak, and die in direct opposition to the thousands of Argentines we are familiar with in the social life." 29 These earlier writers created literature that did not speak of, or relate to the real lives of real people; according to the Contornistas, therefore, it was not even literature. The new generation's demand for engagement brought with it a call for social realism in art and literature.

This same accusation-directed here against Los idolos (1952) of Manuel Mujica Láinez-could be directed at the Martinfierristas and at the collaborators of Sur, such as Adolfo Bioy Casares, Eduardo Mallea, and Jorge L. Borges. A year after publishing his article in Contorno, Prieto devoted a book to Borges, with the purpose of diagnosing in him the same failures he noted in Mujica Láinez: Borges, "perhaps the most important Argentine author today," is nothing but "a great literary figure with no literature." 30 Prieto's book reviews Borges' essays, poetry, and short stories, yet its main objective is political, not literary. For Prieto, the Icelandic sagas and the English literature in which Borges found inspiration, the fantastic tales and detective stories on which he wasted his talents, and his ironies and games were all evidence of an original sin: they omit man. Although he acknowledged Borges as a brilliant writer who could enchant with his erudition and dazzle with his subtleties, Prieto claimed that Borges' brilliance fades quickly: "the magic vanishes."31 For him, Borges represented great erudition put at the service of leisure-class aristocracy, a fabulously expensive suit tailored for only one occasion.

And while this new generation seemed willing to acknowledge that Borges was a writer of importance or, as it was put then, an "indispensable" writer, Prieto made the bold claim that Borges' literary production was quite dispensable after all. For Contornistas, literature must serve; it must transform men and must itself be trans-

27. Sebreli refers to this generation as one that has "the heavy brow of a day of work." He is evidently referring to the modernist movement, one of whose most notable figures in Argentina was Leopoldo Lugones. Sebreli is obviously secking to develop a contrast between the generations of 1924 and 1890-the forner associated with superficiality and the latter with seriousness-not to recover modernism as a literary movement.

28. Adolfo Pricto, "A propósito de Los ídolos," Contorno 1 (1953), p. 5

29. Ibid.

30. Adolfo Pricto, Borges y la nueva generación (Bucnos Aires: Letras Universitarias, 1954), p. 13 and p. 84. This book is imbued with the same spirit found in the pages of Contorno.

31. Ibid., p. 19. 
formed as it is read. Literature must be political; if not, it amounts to worthless pages, written and read for entertainment, nothing more. In many ways, Prieto's critique of Borges may be extended to the generation of 1924. In the time of Martin Fierro and later, in Sur, writers never asked "why or for what end are they writers"; they never wondered "what to do with literature other than jokes, magazines articles, and ceremonial speeches." ${ }^{2}$ This new generation, in contrast, was fundamentally concerned with the conditions of literary production (for what reason?), with its objectives and aims (for what purpose?), and with the action, the praxis (what should we do?) that it might engender. For Contorno, the Martinfierristas lived in an eternal present: "they invented or adopted their own artistic schools, with no contact with the past or with the future; they governed for themselves uninformed by past experience or future need." ${ }^{33}$ The new generation, instead, wanted to revise the past in order to build the future. According to Contorno, the previous generation "did not take their parents seriously and disregarded their children's children," ${ }^{34}$ while this generation gave serious consideration to its fathers, criticized them, killed them, ${ }^{35}$ and imagined a political literature committed to their sons, to the coming generations, to the future of the nation. The Contornistas believed that political acts and aesthetic acts were intimately linked, and they applied this concept not only to literature but to art in general, including film.

In Contorno's first issue, under the pseudonym of V. Sanromán, Ismael Viñas expressed his disappointment with Vittorio De Sica's film, Ladri di bibiclette. De Sica's film, he says, excites with its forms and disappoints with its contents. The critique is similar to those made regarding the Martinfierrista youth: he accused the film of displaying a lack of realism, a lack of engagement, an absence of political art. Ladri di bibiclette is unsatisfactory because it "does not capture life." Viñas's premises are Contorno's: art must involve the artist; art must be moving because of its closeness to its audience and not because of a distance that inspires a more detached admiration; art must address real complications and problems, and capture the complexity and drama of the world as it is. For Contorno, art is not amusing, even when it provokes laughter. Viñas therefore attacked the makers of this cinema as "a bunch of opportunists who blatantly (why not?) maintained that art-their artshould not create complications or problems, nor go beyond satisfying entertainment for the average audience." 36 For Contorno, the purpose of art is not to make us laugh but to make us think. The Contornistas intended to oppose the seriousness of work and an aesthetic politics to the lightheartedness and apolitical aesthet-

32. Ibid., p. 84 .

33. Ibid., p. 88 .

34. Ibid.

35. This attitude of "killing the fathers" is what allowed Rodriguez Monegal to speak about parricide. See Emir Rodríguez Monegal, El juicio de los parricidas (Buenos Aires: Deucalión, 1956).

36. V. Sanromán (I. Viñas), "Ladrones de bicicletas," Contorno 1 (1953), p. 6. 
ics of the Martinfierristas' game. If the youth preceding them wasted the energies of the spirit, the Contornistas intended to stockpile them again.

\section{Writing and Politics}

Contorno dedicated its second issue to Roberto Arlt, who had passed away twelve years earlier. ${ }^{37}$ Honoring Arlt was a political decision that would enable the Contornistas to bolster their critique of complacent bourgeois literature while bringing another target-one no less bourgeois, in their judgment-into the line of fire: the communists. Arlt was, for Contorno, a sincere and powerful writer but also incorrecto (flawed)-and because of this last quality his work had been ignored for a long time. ${ }^{38}$ Many writers-including some Contornistas-shared the opinion that his language was poor, sometimes even rustic, and, in general terms, vulgar. Arlt himself responded ironically to the accusation that he did nor know how to write: "to develop a style, you need basic comforts, income, and time on your hands." 39 Lacking a traditional surname- "Arlt" denoted an immigrant origin, without the aristocratic or traditional markers of writers such as Adolfo Bioy Casares, Victoria Ocampo, or Silvina Bullrich-the writer of Los siete locos belonged to a humble family who arrived in Argentina towards the end of the nineteenth century. His Prussian father and his Italian mother collaborated in the contamination of his Spanish, which from the very beginning was developed imperfectly-characteristic of most of the immigrant families that had arrived in the country at that time. In contrast to the writers attacked by the Contornistas, Arlt represented anti-academicism, anti-erudition, and anti-Eurocentrism. If Borges represented the perfection of form, Arlt was the anti-Borges. If Mallea represented the defense of moral values in literature, Arlt was the anti-Mallea.

Arlt spoke from the margins. If the Contornistas wanted to impugn high literature, if they wanted to question the importance of its works and demystify its writers, there was no better means to do so than promoting Arlt, a proud black sheep of the Argentine literary scene. His work differed from Borges', which is full of archetypal compadritos and characters inspired by European classics and steeped in the notion of a universal literature. By contrast, it was inhabited by "mad rows of ruffians, thieves and prostitutes, child molesters and killers" who indulged themselves "in their misery, their alienation, and their despicable and suicidal lives." 40 They were marginal characters imagined on the margins by a marginal

37. Born in 1900, Arlt devoted himself to journalism and literature, irritating the greater part of the literary circles with his style and language. Some of his most noteworthy works are El jugutete rabioso (1926), Los sicte locos (1929), and its continuation, Los lanzallamas (1931).

38. Ismacl Viñas, "Una expresión, un signo," Contorno 2 (1954), p. 2.

39. Roberto Arlt, Los lanzallamas (Caracas: Biblioteca Ayacucho, 1978), Prólogo.

40. Gabriel Conte Reyes (D. Viñas), “La mentira de Arlt," Contorno 2 (1954), p. 1. 
writer. The Contornistas celebrated this symbiosis between author and work: unlike the writers they rejected, Arlt was not a poser; his characters spoke of what he lived, and he lived as his characters spoke. This identification of author and work, which did not concern writers like Borges, was one of the features of Arlt's work that was most celebrated in the pages of Contorno. ${ }^{41}$ David Viñas, under the pseudonym Marta Molinari, devoted a whole article to unraveling "how much of his internal autobiography did he [Arlt] bring to his characters; to what extent are these characters Arlt himself." 42 The Contornistas used their praise of Arlt to attack those writers in whose work art and life were divorced.

Uneducated, untidy, and unlucky, Arlt represented for David Viñas an attempt to build a life against the grain, with "living beings dissatisfied with the hierarchical world around him." 43 Arlt represented, for Contorno, the recovery of the voice of the weak, the downtrodden, and the vanquished. Ismacl Viñas noticed "his overwhelming outrage at academic rigor mortis," "his clear rise up against the established world," and "his rebellion against European norms." 44 The "living men" Contornistas had looked for in vain in the Martinfierrista generation and in Sur's emblematic writers appeared now in this dark and damned writer who rejected folkloric pretension and employed "everyday language, common, even oafish language, used naturally as the living expression of living men." ${ }^{45}$ Francisco J. Solero found in Arlt the first writer who was not merely a witness of life: "he fought to unveil himself and unveil the sin of not being ourselves." ${ }^{36}$ In short, recovering Arlt meant challenging the writers of the establishment.

Contorno wanted to foster lively discussions of Argentine writing, speech, and language. With Arlt, the bastard dialect of lunfardo entered literature and with it the hidden and feared world of "the underdogs-the land of nobody, that literary academics had proscribed from their work." 47 Arlt ignored the rules of the literary game: he wrote as one hits, as one kicks-clumsily but sincerely. David Viñas

41. Borges believed that "the opinions of a writer are the least important thing he has. Opinions in general are of little value. An opinion or belonging to a political party or what is known as 'politically committed literature' can lead us to admirable, mediocre, or contemptible work. Literature is not so straight forward. It doesn't depend on our opinions. I think literature goes much deeper than our opinions; the latter can change but it wouldn't make our literature any different, would it?" ("Diálogo entre Juán José Saer y Jorge Luis Borges," Crisis 63 [1988], p. 48.) Though this interview is relatively later (1968), I believe it expresses Borges' conception of literature, one that he had already formulated some time before. For example, "We all respect our art and we would never consent to turning it into an instrument of propaganda." (Martin Fierro 8-9 [1927], p. 25.) A similar position may be attributed to Victoria Ocampo who, in 1961 wrote: "We know that the writer does not write for the proletariat, the oligarchy, or the bourgeoisie. The writer writes. The painter paints. And it all depends on what he does well or poorly." (Victoria Ocampo, "A los lectores de Sur," Sur 268 [1961], p. 6.)

42. Marta Molinari (D. Viñas), "Roberto Arlt: una autobiografia," Contorno 2 (1954), p. 8

43. Ibid.

44. Ismael Viñas, “Una expresión, un signo,” p. 2.

45. Ibid., p. 3.

46. Francisco J. Solero, "Roberto Arlt y el pecado de todos," Contorno 2 (1954), p. 7.

47. Fernando Kiernan, "Roberto Arlt, periodista," Contorno 2 (1954), p. 10. 
contrasted Arlt's repugnant "inopportuneness" to the opportune witticism of the literary establishment's acclaimed writer. Such a writer "doesn't compromise himself because to do so he would have to be genuinely responsible"; he must "feel rage at things, feel the world and its people dramatically." 48 Even though Viñas would later confess, more than once, that personally "Borges did not interest him" and that "the polemic was with Mallea," 49 Borges more readily comes to mind when he wrote, "but if you think about his body of work, all his cows coming to slaughter, you notice his gratuitous comments, his momentary affected laugh. His little nothing. His brilliant and very intelligent little nothing. His addition of appetizers." 50

None of the Contornistas judged Arlt a "great literary man," attributed to him, nevertheless, a literature. Francisco Solero's statement on Arlt might well be attributed to Contorno: "With him we were no longer alone in our battle with the monster of conformity; we can conquer. Yes, now and forever, yes." 52 I would argue that for Contorno, Arlt's literature mattered less in and of itself than for its usefulness as a political tool: the Contornistas were less interested in what Arlt affirmed than in how they could use his work to attack other writers and their apolitical aesthetics. From the beginning, the Contornistas' decision to promote Arlt's work was more political than literary. This body of work, written by a man who had left school after the third grade, was considered poor, inconsistent at times, and repetitive. But in political terms it offered a completely different conception of the city, of the people inhabiting it, of the spirit governing them, of their social destiny, and of their political essence. "Man-world-reality"53 was the formula the Contornistas extracted from Arlt for themselves.

Once considered a "nobody," Arlt had become, by the 1950s, just the sort of treasure the leftist intellectuals were seeking. In 1950, Raúl Larra-one of the chief intellectuals of the Argentine Communist Party-attempted to demonstrate that "Arlt was a man who felt attracted to the working class and to the Communist party even though he was never won over by the latter." 54 For communists like Larra, Arlt had understood that "man in capitalist society was a prisoner beating himself against the bars, frantically searching for self-fulfillment and freedom." $55 \mathrm{He}$ therefore placed Arlt as perhaps the first Argentine writer who

48. Dicgo Sánchez Cortés (D. Viñas), “Arlt, un escolio," Contorno 2 (1954), p. 12.

49. See, for instance, D. Viñas, "Nosotros y ellos," p. 12.

50. Sánchez Cortés (D. Viñas), “Arlt, un escolio," p. 12.

51. The probable exception could be Carlos Correas who, much later, would dedicate a book to Roberto Arlt, which was, to a great cxtent, a critique of the opinions expressed in issuc number 2 by Contorno. Sec Carlos Correas, Arlt literato (Buenos Aires: Atuel, 1995).

52. Francisco J. Solero, "Roberto Arlt y el pecado de todos," Contorno 2 (1954), p. 7.

53. Molinari (D. Viñas), "Roberto Arlt: una autobiografia," p. 9.

54. Raúl Larra, Roberto Arlt. El torturado (Buenos Aires: Quetzal, 1950), p. 108.

55. Ibid., p. 41. 
rejected capitalist civilization, inheriting the tradition of the Boedo group in the 1920 s and providing, at last, a literature for the communist cause. ${ }^{56}$

Under the pseudonym of Juan José Gorini, David Viñas answered Larra in the pages of Contorno: "Mr. Larra affirms emphatically 'Arlt belongs to us'. And he is mistaken." 57 Viñas, apparently anxious to protect Arlt's rebelliousness from Communist Party dogma, also used Arlt as a political tool, this time to denounce "that submissive spirit of the firing squad which subordinates itself to communist actions." ${ }^{58}$ His article included many of the opinions the Contornistas shared about the Communist Party and their general sense that its judgmental temperament and credulous pacifism made this form of communism an eminently bourgeois ideology. The Contornistas juxtaposed Arlt's rebelliousness against the conformism of the Communist Party, rescuing his "demonical, aggressive, violent, and sinful spirit" from "the satisfying and progressive safety of the party." ${ }^{59} \mathrm{Con}$ torno used a strategy that would become almost habitual for Argentine leftist intellectuals: to accuse their political adversaries of being purists, especially those who identified themselves as "leftist." The purism they saw in the Communist Party, then, was interpreted as a relic of its members' petit-bourgeois origins, allowing them to live guiltlessly in the bourgeois cloister while waiting for the world's radical transformation. This snobbery, according to Viñas, brought the communists closer to both the Martinfierristas of the 1920s and the famous writers of the journal Sur. no matter which political side they took, they all avoided mixing with the world, with real people, with dirty and harsh reality. Some were theoretically concerned about social reality, while others were shut away in their ivory tower; for Contorno, neither could make a true political commitment.

\section{Existence AND Politics}

Engagement and literature were inseparable for the Contornistas. Yet this engagement had little to do with universalistic concerns for humanity's well-being or transcendental moral values. For Contorno, those practicing this sort of false universalistic engagement were Sur's acclaimed writers, especially Victoria Ocampo and Eduardo Mallea. ${ }^{60}$

56. Even though they did not call themselves "communists," the social preoccupation characterizing this group made it possible for them to be regarded as the first progressive writers of the twentieth century. Among others, the members of the group of Boedo were Elías Castelnuovo, Leónidas Barletta, Nicolás Olivari, Roberto Mariano, and Álvaro Yunque.

57. Juán José Gorini (D. Viñas), "Arlt y los comunistas," Contorno 2 (1954), p. 8.

58. Ibid.

59. Ibid.

60. Masotta summarized Sur's engagement as follows: "Sur swore by 'free thought', by 'the West', the 'human subject', and added: "but, sad but true, the proletariat found itself excluded from the world of these lofty values." (Masotta, "Sur o el antiperonismo colonialista," p. 45.) 
Contorno's third issue opened with a powerful article by Adelaida Gigli attacking Victoria Ocampo. Even in her title, Gigli ironically denounced Ocampo's social class; including in the title the letters "V. O.," the author reminded the readers of Ocampo's high-class origins, of that social and cultural elite who used to inscribe their initials on their clothes. Her engagement with the feminist causeOcampo had founded one of the first feminist Argentine movements, the "Unión de Mujeres" (Women Association) - did not suffice to exempt her from the Contornistas' harsh critiques. Gigli considered Ocampo a kind of cultural voyager, "a smart girl," a young woman "with a fervent belief in humanity."61 She had studied in Paris' prestigious Sorbonne, she spoke several languages, and some of her acquaintances were the greatest personalities of the local and international literary world; in short, Ocampo "had no country." Her cultural voyage-and her constant showing off of the knowledge she gained along the way-served only to feed her own self-satisfaction and reaffirm her own selfimage. Gigli wrote that from her "Testimonios," for instance, there is one conclusion to be drawn: "I-I-I. Me-me-me." 62 Ocampo's apparent passion for universal literature was, alas, put at the service of only one individual: herself. In summary, "there will not be literature; there will be Victoria Ocampo." ${ }^{63}$ And it was not only Gigli who attacked Sur's chief representative. Other Contornistas, such as Ramón Alcalde, came to similar conclusions, ironically emphasizing their disdain for Ocampo's voyeuristic attitude towards literature: "Victoria sought out, in European literature, semi-goddesses with whom she could have tea and then talk about it in La Nación [the aristocratic Argentine newspaper], or semigods with whom she could go out at night." 64

Contorno's trademark irony was again brought into play in Rozintchner's more powerful critique of Mallea's work. This criticism had three vectors: first, it criticized moral purity as a status symbol; second, it criticized his literary narcissism as intellectual pedantry; finally, it identified the bourgeois nature of his literature. Mallea's work was, according to Rozitchner, filled with a "high formal morality" that made readers feel "the same annoyance we feel when we open up a moral manual: we are under the control of dichotomous words that pretend to preach abstractly but are cut with pious slaps, in a tone of admonishment, a universe in which the translucent nature of the writer finds itself excluded." 65 For Rozitchner, Mallea flaunted his knowledge in order to underscore the ignorance of the rest of Argentinean society.

61. Adelaida Gigli, "Victoria Ocampo: V.O.," Contorno 3 (1954), p. 1. 1977.

62. Ibid., p. 2. From 1935 on Victoria Ocampo published a long series of testimonies which would continue until

63. Ibid., P. 1 .

64. Ramón Alcalde, "Imperialismo, cultura y literatura nacional," Contorno 5-6 (1955), p. 58.

65. León Rozitchner, "Mallea y nuestras vergüenzas," Contorno 5-6 (1955), p. 31. 
While Sur's readers and critics ${ }^{66}$ praised Mallea's attempt to recover an ethics that they considered lost in the midst of a corrupt time, Contorno denounced him. "[B]y dividing good from bad so drastically," he established such "distance between the moral world and reality" that "the moral universe remained trapped in its verbal expression." ${ }^{67}$ Contorno believed that Mallea extolled universal moral values (thus, bourgeois values), ${ }^{68}$ but they also believed that his surreptitious intention was to condemn (as a judge or as a god) both an impure social reality and the men who were thrown into a series of small depravities and large transgressions. ${ }^{69}$ Toward the mid 1950s, this judgment, which distinguished good and evil as well as pure values from corrupt ones, also distinguished Sur's liberal antiPeronism from the Peronist form of populism in power.

From his moral pulpit Mallea thus distanced himself from mere mortals as a teacher distances himself from his pupils or a prophet from his disciples, and he exhibited in his books knowledge that Contorno judged at once erudite and empty. In Rozitchner's view, this intellectual pedantry served both to separate Mallea from the "the unhappy poor" who read his work and admired him, and "to acquire the esteemed bourgeois rank of writer." 70 If Contorno had aimed to place Victoria Ocampo squarely in the Argentine oligarchy, in the case of Mallea they tried instead to highlight the class markings in his literature, which followed "the bourgeois game in which everyone showed themselves as politically correct [...], love became an outward gesture, sex became spiritual, and purity became an end."71 In other words, on the altar of form Mallea sacrificed content; in the pursuit of the "pure" universal, Mallea looked down on "impure" immediate reality; in his elitist intellectualism, Mallea revealed his bourgeois origins. ${ }^{72}$

Contorno thus identified two broad camps. On the one hand, we have those who used literature to judge reality in moral terms (Mallea), avoided becoming engaged with reality by means of fantastic stories and intelligent witticisms

66. For instance, the cultural supplement of La Nación, which was directed by Mallea himself.

67. Rozitchner, "Mallea y nuestras vergüenzas," p. 31.

68. In a later article, Rozitchner summarizes "the values of the bourgeoisie: ascetic love and respect, fanily stability, liberty for all, the sanctity of the church, work in the factories at full production, patriotism, good customs, ctc." (León Rozitchner, "Experiencia proletaria y experiencia burguesa," Contorno 7-8 [1956], p. 6.)

69. See Eduardo Mallea, Historia de una pasión argentina (Buenos Aires: SUR, 1937).

70. Rozitchner, "Mallea y nuestras vergüenzas," p. 34.

71. Ibid.

72. The Contornistas did not ignore the fact that they also hailed from the bourgeoisie, although they tended sometimes to underestimate its importance. Rozitchner was, for instance, clearly one of the Contornistas that most emphasized the fact that they not only had to fight an external enemy, the bourgeoisie, but also an inner one: that which was still bourgeois in them. "Between us and the workers, there is an abyss," Rozitchner wrote, later on pointing out that such abyss was at the same time profound and exciting. (Rozitchner, "Experiencia proletaria," p. 4.) The Contornistas questioned any literature that, according to them, acclaimed the bourgeois world, and defended a type of literature that, although originating in the bourgeoisie, was destined to question and undermine such a world. 
(Borges), or exhibited their aristocratic credentials in order to gain access to an elite European intellectual ghetto (Ocampo).$^{73}$ On the other, we have a new generation of engaged writers who were willing to consider, before any aesthetic aim, their own situation. These engaged writers preferred to treat history as an existential drama. In the Contornistas's view, writers had the task of translating such drama into literature, not to show the world how it should be but to give themselves unto it and to reveal its secrets. Sartre's impact on Contorno was such that it conceived of its own existence as essentially literary as well as existential. ${ }^{74}$ Almost half a century later, Sebreli would remember this attitude as a "total literaturization of our existence. We deluded ourselves into transforming everything we read into reality and writing about everything we lived; we made literature our lives, and our lives literature. We could not conceive a thought if it wasn't written, an experience was not a real experience unless it could be narrated." ${ }^{\prime 75}$ In making their existence literary, the Contornistas implied the politicization of the way they read and wrote literature.

\section{Nation and Politics}

Contorno was taken to the streets by the spreading of flyers with the following announcement: "Contorno, revista denuncialista." Contorno had established as one of its tasks, among others, to denounce those who had prevented, with their work and their thinking, the knowledge of the "national being," of "finding out who we are." "Contorno's more or less explicit diagnosis of the Argentine Nation was that Peronism represented the most visible sign of the collapse of a fantasy. For decades, Argentines-and with them, the intellectuals and, especially, the literati-had displayed "the glowing structure that they had taken to be the Nation" and had lived in the illusion of sharing "an easy and optimistic future."77 They had lived, in the Contornistas' judgment, in an apparent order; they had lived on the surface of the Nation, ignoring its underground, its depths, and its secrets.

The colonial traditions-those formulas in whose name a total reorganization had been carried out-sustained a structure of legality, order, and norms (politically, juridically, economically, culturally) that was quite different from reality and, in part, at its expense. ${ }^{78}$

73. The names in brackets are not the only ones to whom the Contornistas attributed these attitudes, but they are undoubtedly the most emblematic.

74. This group was formed by Masotta, Sebreli, and Correas.

75. Sebreli, "La operación Correas," Dossier.

76. Ismael Viñas, "Reflexión sobre Martínez Estrada," Contorno 4 (1954), p. 2.

77. Ibid.

78. Ibid. 
According to Contorno, reality itself was dislocated until the coming of Peronism, when "in fact, the break with apparent order"79 became visible. Contorno committed itself to analyzing this break. In order to do so, they assumed responsibility as a guilty "we." This "we" included both the generation preceding the Contornistas and themselves, as members of a new generation who wanted to take responsibility. Contorno, whether to emphasize its engagement with and responsibility for national problems or to feel more entitled to a radical critique of the attitudes and positions it impugned, denounced "others" but blamed the situation on an "us." "Today," they affirmed, "we are all guilty," given that "the others are ourselves." Thus, they committed themselves "to write and to live as guilty people." 80 This attitude was well summarized in Viñas's motto: "Become responsible by denouncing."

The recovery of Martínez Estrada's work took place within this context. ${ }^{82}$ The Contornistas dedicated their fourth issue to the author of Radiografia de la pampa (1933), and, despite their different nuances, the articles in that issue implicitly proposed the following thesis: Martínez Estrada's written word constituted much less than its spirit; its spirit transcended and nourished us. Martínez Estrada had distinguished himself from other writers of his generation by means of his denunciatory tone; he had not written to please but to question, and he had spoken more of the impediments than of the possibilities of the Nation. In $L a$ cabeza de Goliat (1940), for instance, he argued that Argentina had built a great city (Buenos Aires) because it had been incapable of building a great nation, that the opulence and wealth of the porteños were nourished by the misery, the backwardness, the ignorance, and the isolation of the provinces. He believed that Argentines' own faith in their future was directly related to their incapacity to look backwards (toward the past) and inwards (toward the interior of the country). These ideas greatly inspired the Contornistas.

Yet it was a limited inspiration. Martínez Estrada was presented, in almost every article devoted to him, as an author of two sides, one more acceptable than the other. In short, his catastrophic vision of the nation was right; his skeptical conclusion was not. ${ }^{83}$ To be aware that Argentines had been expelled from paradise did

79. Ibid. The impression of living at a time when an honest discussion of national reality could take place can be traced in several issues of the journal. In the Editorial of the issue of 1955 they said: "Nonetheless, it seems that the need to face reality is being felt again." (Editorial, "Terrorismo y complicidad," p. 1.)

80. David Viñas, "La historia excluida: ubicación de Martínez Estrada," Contorno 4 (1954), p. 16. Also Troiani insisted on this guilt: "We feel guilt; we know ourselves to be guilty." (Osiris Troiani, "Examen de conciencia," Contorno 7-8 [1956], p. 9.)

81. David Viñas, "La historia excluida," p. 16.

82. Born in 1895, Martínez Estrada had already become, towards mid century, the most transcendent Argentine essayist. His works include Radiografia de la pampa (1933), La cabeza de Goliat (1940), and Muerte y transfiguración de Martin Fierro (1948).

83. Once Contorno disappeared, Sebreli devoted a book to the "negative" aspect of Martinez Estrada's work. See Juan J. Sebreli, Martinez Estrada. Una rebelión initil (Buenos Aires: Palestra, 1960). 
not necessarily condemn writers to the mere task of "painting hell." 84 For Contorno, Martínez Estrada initiated a project they wanted to continue. With him, the country had started to gain self-consciousness, and intellectuals had been called to abandon the mere contemplation of reality and to engage it. Nevertheless, no overarching synthesis, no politics could be expected from the simple acceptance of a dualist character that, beginning with Sarmiento's "civilization and barbarism," constituted the nation. And this was the task Contorno seemed to set for itself: to search for a way to supersede the extremes that defined the Argentine nationality. ${ }^{85}$

\section{Situation and Politics}

Until the fall of Peronism in September 1955, some Contornistas had referred only tangentially to that movement and its leader, implying rather than asserting the despotism and populist demagogy that characterized both. But finally, in the issue of July 1956, the Contornistas confessed what their readers already knew, that "during all those years of Peronism we never succumbed to [it]." 86 Thus, they confirmed their position within the intellectual field, which was chiefly not Peronist. Yet they immediately differentiated themselves from the other anti-Peronists, especially from Sur. ${ }^{87}$ "What we understood as 'never succumbing to Peronism' was not only resisting Peronism but also anti-Peronism." 88 Contorno aimed to moderate its past opposition to Peronism and to emphasize its new position as being anti-anti-Peronist. ${ }^{89}$ This double negation was manifested through

84. I. Viñas, "Reflexión sobre Martínez Estrada," p. 3.

85. It was clear that the most salient duality when these articles were published was Peronism/anti-Peronism. Nevertheless, the Contornistas' attempts to achieve a synthesis that could supersede Argentine contradictions went beyond that duality. The brothers Viñas, Sebreli, Kush, and Solero all used a dual logic in their explanations of Argentine history and its present conditions. For Sebreli, see "Celeste y Colorado," Sur 217-218 (1952); for David Viñas, see "La historia excluida"; for Ismacl Viñas, see "Reflexión sobre Martínez Estrada"; for Solero, see "Primera aproximación a Martínez Estrada," Contorno 4 (1954); and for Kush, see "Inteligencia y barbarie," Contorno 4 (1954). The intention to supersede these dualitics was manifested in the Editorial of the issue that Contorno dedicated to the Argentine novel.

86. Editorial, "Peronismo... jy lo otro?," Contorno 7.8 (1956), p. 1.

87. Barely two months after Perón was overthrown, Sur published its famous issue 237, under the motto "For National Reconstruction." Almost all its collaborators celebrated the fall of Peronism. The Contornistas mocked Sur's enthusiasm and harshly criticized its anti-Peronism. Ismael Viñas, for instance, wrote: "The well-known journal issue 237 of Sur is an encyclopedia of smugness; evcrybody so sure of the Truth; their Truth; my Truth; all of them with a good and clear conscience. All of them were insistent that we should teach the Truth (my Truth, our Truth) to the swindled poor. Nobody has a doubt." (Ismael Viñas, "Miedos, complejos y malos entendidos," Contorno 7-8 [1956], p. 13.) Although the Contornistas numbered themselves among those who had suffered "personally the long term of the Peronist process," they believed that, even under those conditions, it had been possible to think, to speak and to write. For Contorno, the repressed liberties denounced by Sur's writers during the ten years of Peronism were an excuse to justify their lack of commitment within the political field. On the contrary, the members of Contorno felt they had "fought with little or great effectiveness, successfully, and unsuccessfully to bring out the truth about what was going on in the country." Contornistas said they were "individuals who wrote wet after the rains" and thus, they distinguished themselves from Sur's writers, who they believed were "dry, intact, men of the world." (Editorial, "Peronismo... cy lo otro?," pp. 1-2.)

88. Editorial, "Peronismo... ¿y lo otro?," p. 1

89. Sebreli explained this change in his position as follows: "Contorno's intention was to be against Peronisn when Peronism was official. The journal dedicated to Peronism was something different because at that time the Peronists were being persecuted and our position changed. It wasn't the same when Peronism controlled the state as when Peronism 
a new affirmation. Contorno's issue no. 7-8 denied Sur's liberalism (which, in turn, denied Peronism) by affirming Peronism—once it had fallen —or by affirming what Peronism had meant. Therefore, many of the reflections appearing in this issue may be considered a critique of the positions Contorno had taken during the Peronist government.

Contorno established as its urgent task to unravel what had happened in Argentina during the ten long years of Perón's government. Nevertheless, in order to do so, they preferred to take into account Peronism and leave aside the question of Perón himself. In issue 7-8 of Contorno, on the one hand they refer to the movement's leader with words intended to minimize his importance and his role within the movement (they called him "that insignificant man," 90 "the social climber," and "nothing more than a puppeteer"92). On the other hand, they rescue the Peronist experience as the moment of emergence of a proletarian consciousness, trying to "see the world as they [the proletariat] saw it." "93

This last task-destined to become a common aspiration for the intellectuals of the next decade-was carried out with a vanguard spirit that Contorno did not fully intend. For example, Rozitchner wrote of the Contornistas that "our position was that of those who could see things from various angles while the proletarian only saw one." Of the working class he stated, "there is in the proletariat a consciousness, though vague, a sensibility though dulled, of the goals that will lead to their own advancement." 94 Rozitchner's point of view, clearly the result of a Marxist analysis, was reinforced in the same issue and from the same epistemological frame by Oscar Masotta, who wrote, "Nobody goes against their own interest more than the worker himself, said Marx. And what does this mean other than we must help the proletariat free themselves of their current mindset and this freedom will only come with the on-going unmasking of bourgeois ideologies?"95 Three years later, when explaining the thrill the Contornistas felt upon witnessing the great Peronist demonstrations, David Viñas expressed a sentiment similar to that of Rozitchner and Masotta: "It occurred to us that if we added two or three concrete ideas which we supported to the workers' disorganized agenda, it could turn into something formidable." 96 These and similar opinions serve to support Katra's claim that the Contornistas had "vague desires to establish a dialogue with

was persccuted [.. .] so when Peronism fell and was converted into the proscribed party, it acquired a certain sympathy at Contorno." (Interview by author.)

90. Troiani, "Examen de conciencia," p. 9.

91. Juan J. Sebreli, "Aventura y revolución peronista. Testimonio," Contomo 7-8 (1956), p. 46.

92. Rozitchner, "Experiencia proletaria," p. 4.

93. Ibid., p. 3.

94. Ibid., p. 6.

95. Masotta, "Sur o el antiperonismo colonialista," p. 45.

96. David Viñas, "Una generación traicionada. Carta a mis camaradas de Contorno," Marcha 992 (1959), p. 14. 
the working class." ${ }^{97}$ Indeed, their dream seemed to be to orchestrate that dialogue (at least in cultural terms).

When Peronism fell, the Contornistas thought specifically for the first time of proposing a political project that could include the proletariat and that, at the same time, could overcome the Peronist/anti-Peronist dualism. Contorno assessed recent and contemporary political situations and tried to find not only an explanation of reality but also "a language that facilitated our communication with the multitudes who believed in Perón."98 The Contornistas were aware that "between the proletariat and us [the Contornistas, although more broadly, the intellectuals] there is an abyss." 99 They therefore wanted to establish a common language, one that was not demagogic, as Perón's had been, and that, at the same time, had Perón's effectiveness, making the leadership of the masses possible. This problem of communication between intellectuals and the people would be one of the fundamental topics of debate during the two next decades. ${ }^{100}$

The Contornistas insisted on one basic tenet to counter Sur's liberalism: ${ }^{101}$ Peronism was not fascism. "Undoubtedly, Peronism was not a form of fascism; it was at a minimum the result-or rather the residue, unforeseen by everyone, including its founder and beneficiary - of an attempt at fascistic reform of Argentinean political life." 102 Halperín Donghi blamed the fascist situation on circumstances that predated the Peronist experience. For Donghi, fascism had appeared on the political scene in Argentina in 1930, with Uriburu's coup d'état to restore the conservative republic. Peronism was the result of almost fifteen years of a fascist situation, but - and perhaps against its own will—it was not fascism; it could not be.

In the same issue, Rodolfo Pandolfi and Sebreli expressed the same line of thought. Pandolfi put special emphasis on the political difference that should be drawn between June $4,1943,{ }^{103}$ and October $17,1945 .{ }^{104}$ Whereas the revolution of 1943 meant "the political predominance of the reactionary and totalitar-

97. Karra, Contorno. Literary Engagement, p. 119.

98. Rodolfo Pandolfi, "17 de Octubre, trampa y salida," Contorno 7-8 (1956), p. 22.

99. Rozitchner, "Experiencia proletaria," p. 4.

100. For an analysis on this conflictive relationship see Carlos Altamirano, "Intelectuales y pueblo," in Altamirano, La Argentina en el siglo XX (Buenos Aires: Ariel-Universidad de Quilmes, 1999).

101. As Altamarino pointed out, in Sur's eyes "The decade of Peronism had been a shaneful and irrational decade and its contributors wrote, confident that they could rely on the agreement of their readership on this point. They also relied on the idea of Peronism as a totalitarian phenomenon, a mixture of fascism and Rosisn constructed ten years before." (Altamirano, "Estudio preliminar," p. 20.)

102. Tulio Halperín Donghi, "Del fascismo al peronismo," Contorno 7-8 (1956), p. 15.

103. This was the date of the coup d'état by a nationalist faction of the army, led by Farrel. Perón participated in it and was appointed Secretary of the National Labor Office.

104. On October 17, 1945, Perón, who was imprisoned in the Milizary Hospital by order of the dominant faction of his military peers, was released. 
ian sectors nourished by Nazism," October 17 showed "the definitive break with the past, not only because it put an end to the old political solutions the people continued to hold, but it also put an end to the 4th of June," the date that marked "the brief clerical-falangist experiment, seemingly its culmination but in reality its contradiction." 105 Sebreli, for his part, found it "an abomination to compare Peronism with fascism," because while fascism's support came from the middle class and constituted an anti-worker movement, Peronism had its base in the working class. Moreover, fascism is defined "by its seriousness [...] [but] if there is anything that embodies the antithesis of rigidity, solemnity, and colonial and monastic frame of mind, representative of the catholic-fascist spirit, it is precisely Peronism." 106 In short, Contorno described Peronism as a movement engendered by fascism but fundamentally devoted to the working class or national-populism. ${ }^{107}$

Some of Contorno's collaborators, in their prolonged discourses about the meaning of Peronism, even offered a sort of exoneration for Perón's adherents, departing from the stance they had taken in previous years. Perón is clearly depicted in many articles as an impostor, a con man, a demagogue; but Perón did not matter. Peronism, instead, had been the Argentine proletariat's most significant experience, and, as such, it did matter. For Rozitchner the proletariat had been the "victim of the crazy but necessary adventure" conducted by Perón; it was an available mass in the hands of a demagogic military man. Nevertheless, the proletariat had "historically been correct." 108 In other words, beyond its will or conscious-

105. Pandolfi, “17 de Octubre,” p. 26.

106. Sebreli, “Aventura," p. 48.

107. Except for Halperín Donghi, the attempt to separate Peronism from fascism should be seen more as a political position adopted by Contorno vis-à-vis their opponents than as a deeply rooted conviction stemming from a serious and reflective analysis. Claiming that Peronism and fascism were different would have implied not sharing the liberal judgement that linked them. Everything seems to suggest that, at some deep level perhaps not consciously recognized at the time (some of them later even wrote about it), many Contornistas believed that Peronism had been a local version of fascism, watered down and attenuated. Sebreli explained his change of position in the following statement: "Later I changed my mind. At that moment I confess that my cultural politics was limited. My political theory was also limited. 1 read a lot of literature, as 20 -year-olds are prone to do. I read a bit of sociology, but very little political theory. I studied fascism later [. . . ] Peronism was trying to be fascist. I applied ideas borrowed from Sartre. The term 'spirit of seriousness' is obviously a Satrean term, but it can also be said, though not in the case of German fascism, because of course it was very serious, but in the Italian case there were similar elements. Mussolini sunbathing on the beaches and what do I know, perhaps Italian fascism did not have such a 'spirit of seriousness,' and at the same time Peronism incurred 'a spirit of seriousness,' by which I mean a mix of transgression and a 'spirit of seriousness'. The flag and the military parades, total respect, at first by the army, the church, and the institutions, and on the other hand, Evita out of control. It was a mix of both things. In the same way as other arguments that I put forward (onc of which is still being used today)-that fascism is a middle-class movement and Peronism is a working class movement-that too is mixed up. But there were working-class supporters of fascism and middle class supporters of Peronism." Sebreli considered this to be a shared confusion; nobody in Contorno had a clear idea of what fascism really was. "I thought that nobody was really clear, not even Ismacl, who was the only one who had a political thought at that time (although it wasn't much), that it was fascism itself that did not have a clear understanding of what fascism was. Fascism was at that time what can be vulgarly referred to as a dictatorship, oppressive, terroristic. The characterization that fascism was basically a movement supported by the masses never entered their minds and it perturbed even me to see the masses in the street. And that was fascism. But this was not well looked upon because of a lack of understanding - a real political understanding of what fascism was." (Interview by author.)

108. Rozitchner, "Experiencia proletaria," p. 3. 
ness, beyond its alienation, and, of course, beyond its leader, the proletariat continued to be the revolutionary subject. Pandolfi defended both the workers' Peronist feelings and the need to consider revolutions for what they are and not for what they should be. "There is today a fruitless wish to scandalize the Peronist worker," he wrote, but "he will not feel shame for having been-or for continuing to be-Peronist." 109 In that same article, Pandolfi pointed out that revolutions are what revolutionaries make of them, alluding to the way in which Peronism had revolutionized Argentine politics and culture. For Pandolfi, Peronism was the form that revolution had assumed in Argentina. Sebreli, for his part, regarded Eva Perón as a collective Cinderella, defending her social origin ("Evita, also lumpenproletariat herself," Sebreli wrote) and coming close to proclaiming her an avenger of the humble class.

Furthermore, despite the fact that the principles of Peronism (social justice, economic independence, and political sovereignty) had not been thoroughly put into practice, Sebreli believed that these principles took hold in Argentina thanks to Peronist propaganda. He therefore claimed that "all generations of Argentines were educated in that revolutionary language absolutely unknown before Perón." 110 Sebreli went even further, justifying Peronist demagogy as a means to awaken the consciousness of the working class:

Being a demagogue, Perón has not degraded the consciousness of the proleteriat, as the lovers of the painless revolution and the odorless workers claim, because in a society divided into classes all consciousness is degraded from birth and nobody can degrade it further. It is true that Perón lied to the workers making them believe that they were the government, when in truth, they weren't. But the positive side of this lie was that the workers were getting used to the idea that they could and should be the government, that the government was their business. For that reason Peronism was not the substitute for the social revolution but its forerunner. ${ }^{11}$

For most Contornistas, Peronism was neither a social revolution nor its consequence; it was its prologue. Some years later, the suspicion that a social revolution was imminent would become a certainty.

Contorno's self-assigned task was to distinguish, to clarify, to order. As the journal put it in the editorial for issue 7-8, “[w]e propose to take the risk of saying: this from the Peronism, 'yes'; that from the Peronism, 'no'." The fight of the Peronist masses, yes. Perón's absurd passion, no. Collective resentment mobilized, yes. That resentment put in the service of a con man, no. Peronist flags,

109. Pandolfi, " 17 de Octubre," p. 23

110. Scbreli, "Aventura," p. 49.

111. Ibid. 
yes. Their demagogic waving, no. In short, it may be stated that Contorno's conclusion was "yes" to Peronism and "no" to Perón. Paradoxically, this conclusion, drawn by the intellectual left representing Contorno, was not too dissimilar from the trade unionist objective that, years later, Augusto Vandor would embody: in both cases, the aspiration was to create a Peronism without Perón. ${ }^{112}$ In this way, Contorno attempted to adopt an intellectual position that would distance them from the Peronist/anti-Peronist dichotomy, as others would try to do in the following decades. As Silvia Sigal points out, in Contorno we find an authentic effort to define a new space for intellectuals and a new relationship between culture and politics. ${ }^{113}$

During the next two decades, one of the fundamental issues dividing the intellectual left would be precisely whether the revolution should be carried out with Peronism or against it. Opposing the Marxist left, who saw in Perón and his movement an obstacle to revolution, Peronist revolutionaries such as John William Cooke held that a revolution requires a revolutionary party, revolutionary leaders, and a revolutionary myth. From this leftist Peronist point of view, Argentina had in Perón the last two elements; what remained was to create a revolutionary force that could later take advantage of the situation. ${ }^{14}$

Differing from other intellectual groups who wished to see in Peronism a sort of nightmare, a bad dream from which the country had already awakened, Contorno and all its collaborators accepted Peronism as a fact. They never raised the question of whether the country would have been better off had Perón never appeared, nor did they assume that Argentina would emerge unchanged from the Peronist experience. This approach to Peronism was manifested in heterogeneous ways. Some writers criticized the proletariat's attitude. Rozitchner, for instance, condemned-through an analysis very much indebted to the Hegelian dialectic of master and slave - the proletariat's passivity, their inability (or unwillingness) to fight for their own interests, and their facile celebration of "their political meetings protected by the police, with handouts and sweet bread." The proletariat received as a handout all that they should have fought for. For Rozitchner,

[t]here were no obstacles to overcome: they were overcome by decree; there was no unity to achieve: unity was achieved by automatic affiliation; there were no salaries to fight for: raises were decreed from above; there was no culture to surmount: it over-

112. Augusto Timoteo Vandor was one of the main unionist leaders during the Peronist resistance. His attempt to arrive at a "peronismo sin Perón" ended up by infuriating Perón and started a fierce fight for unionist power, from which Perón came out victorious.

113. Silvia Sigal, Intelectuales y poder en la década del sesenta (Buenos Aires: Punto Sur, 1991), p. 150.

114. See Correspondence of J. W. Cooke, in Richard Gillespie, J. W. Cooke. El peronismo alternativo (Buenos Aires: Cántaro, 1989). 
flowed from the very same passions that were placated by instant gratification, without any future. ${ }^{115}$

Nevertheless, the same author-the toughest of the Contornistas in evaluating proletarian support-exempted the working class from all guilt: the proletariat had been misled. And the reasons for that deception were completely understandable, as Perón "was the first to propose concrete goals [to the workers] that matched their interests."116 For Rozitchner, the concrete gains for the working class made during the Peronist regime were, paradoxically, not the end of the revolution but its beginning, for only then did that class become aware of its historical role. Once the mistake of the proletariat had been explained and justified, the challenge of leading them toward a truly emancipatory aim remained. Like other intellectual and political groups, Contorno underestimated the bond between Perón and the masses, an error that led to their enthusiastic support of Arturo Frondizi's campaign. They saw Frondizi as a less demagogic and more intellectual leader than Perón, and they attributed to him a popular and leftist program. ${ }^{117}$ In addition to the active participation of a number of Contorno's collaborators in the electoral campaign, some of them came to hold public office during Frondizi's first term. ${ }^{118}$

But Frondizi's desarrollista government rapidly disappointed leftist groups and even Contorno. In particular, his oil policy, which included contracts with multinational companies, and his educational policy, which made it possible for private universities to be established, led the Contornistas to feel that they had been betrayed. In fact, Contorno's last issue (9-10) was wholly devoted to an analysis of "the Frondizi betrayal." If Perón had deceived the proletariat, Frondizi had now deceived them, the intellectual elite, and in the pages of Contorno they confessed they "had been tricked as if they were children" by Frondizi. ${ }^{119}$ Rozitchner's disappointment was the disappointment of a whole generation of young leftist intellectuals: "The difficult thing is to admit the following: this call that evoked a unanimous response was later frustrated. This is what gives a stain of betrayal to the present leadership of the government. Only Frondizi could betray the very fervor that he had stirred up and helped to prepare." ${ }^{20}$ The concern over how intellectuals could maintain

115. Rozitchner, "Experiencia proletaria," p. 4.

116. Ibid., p. 3.

117. Arturo Frondizi presided over the government from 1958 to 1962 . Towards 1957, his differences with the radical leader Ricardo Balbín regarding how to link their movement with Peronism provoked a split within the Unión Cívica Radical (UCR), which divided into the UCR del Pueblo, led by Balbín, and the UCR Intransigente, led by Frondizi. Frondizi came to power after celebrating a pact with Perón, by virtue of which, in exchange for the Peronist votes, Frondizi promised to develop a popular program close to that of Peronism.

118. In the first Cuaderno de Contorno, published in 1957, Contorno expressly supported Frondizi's candidacy.

119. Rozitchner, "Un paso adelante, dos atrás," Contorno 9-10 (1959), p. 2.

120. Ibid. Rozitchner afterwards denied he had taken part in the Frondizist enthusiasm. Although he recalled that "Frigerio called on us as a group because they wanted us to join the radicalism movement," he "felt ambiguous" when 
a dignified position vis-à-vis power-a concern that Oscar Terán raised in the 1960 s-made an early appearance in this issue of Contorno. ${ }^{121}$

Contorno's issue 9-10 was rounded out by a long analysis of the political situation ${ }^{122}$ by Ismael Viñas and a thoughtful work by Halperín Donghi on the reading of the Frondizi experience from a historical perspective. ${ }^{123}$ The three pieces in the issue differ in purpose and method. Nevertheless, the three share a common tenet: that social change is possible only if there is, on the one hand, a true commitment to it and, on the other hand, a true communion with the masses.

Halperín Donghi compared two different historical situations, the situation of $1837^{124}$ and that of 1958 , and found a key common characteristic. The men of both generations-enlightened men who had become politicians-having defended a break with the past, once in office ended up reinforcing the old structures of power that they allegedly intended to abolish. Halperín Donghi therefore concluded that

we can quickly learn a lesson that seems to apply to both 1837 and 1958 . These revolutionaries couldn't carry out a revolution because they never put themselves at the service of a real revolutionary force; divorced from the people, their revolution could be nothing more than that of the dominant groups who always and quite quickly find their limits. ${ }^{125}$

Rozitchner placed special emphasis on the role they were meant to play, as leftist intellectuals, in social transformation. The problem extended beyond whether Frondizi had betrayed them. In his view, "even when Frondizi's intentions coincided with our own, he will not do those things we should do our-

\footnotetext{
he was offered a position as an advisor after Frondizi won and Ismael Viñas was appointed Deputy Director of Culture. He stated bluntly: "I was never a Frondizist." When faced with the need to explain the use of "nosotros" in his article "Un paso adelante, dos atrás," in which he addresses "the Frondizi betrayal," Rozitchner declared that he had found himself "drawn into Frondizism by his friends from Contorno, David [Vinas], above all, Ramón [Alcade] and by Ismael [Vinas] but I, at the beginning, was never a Frondizist. When I say this it is as if I am taking responsibility for what they could not say because they were so involved, and well, for that reason we, the 'we' to which I belonged-because I am interpreting something that happened in the group - was out of necessity, but I was the least convinced by their ideas." (Interview by author.) Sebreli made similar declarations, denying any kind of personal enthusiasm in the Frondizist adventure: "The trio [Masotta, Correas, and he] never supported (were never really behind) Frondizi. Even though we did vote for him, we voted because, who else was there to vote for? Balbín? Were we really going to vote for Balbín? We voted for him but with no illusions, unlike the Viñas brothers, Jitrik, Rozitchner, Alcade, who deluded thenselves into being hopeful that they would be the intellectuals of the new country." (Interview by author.)

121. See Oscar Terán, Nuestros años sesentas (Buenos Aires: Punto Sur, 1991).

122. The article is called "Orden y Progreso," which, with certain modifications, would be published in book form a year later. See Ismael Viñas, Orden y progreso. La era del frondizismo (Buenos Aires: Palestra, 1960).

123. Halperín Donghi, "El espejo de la historia," Contorno 9-10 (1959), 76-77.

124. The young intellectuals and politicians Alberdi and Echeverria, among others, belonged to this generation.

125. Halperín Donghi, "El cspejo de la historia," p. 77.

126. Rozitchner, "Un paso adelante, dos atrás," p. 7.
} 
selves." ${ }^{126}$ The issue was not, then, about asking the president-as a child asks its father-to fulfill his promises; rather, it was about taking charge of their own situation and doing what they had to do while the president did what he had to do: "Frondizi has delegated to the people what he can't or doesn't want to do. It is necessary then, that we be the ones who take charge of this duty left by the wayside by the present government of Frondizi." ${ }^{27}$ For his part, Ismael Viñas, after underlining what his generation had learnt-a generation that "has gone through exceptional experiences: the war, the Cold War, the people's uprising in Asia and Africa, Justism, ${ }^{128}$ Peronism, the military government, and Frondizism"-claimed that the task of the left was to become "new men for a new situation." ${ }^{29}$ A few years later other "new men," prepared to launch the revolution, exchanged pens for arms.

In January of the same year in which Contorno's last issue was published Fidel Castro and Che Guevara's armed uprising triumphed in Cuba. Revolution was possible. ${ }^{130}$ That sense of possibility, which would be one of the most prominent features of Argentine politics in the next two decades, was already evident in this last issue of Contorno, where, rather than debate the likelihood of the revolution, they reflected on what to do in order to make it happen: "The situation that we are living pushes irresistibly to this new world; [ . . ] our task consists of collaborating with this birth, with hastening history."131 Contorno is an exceptionally useful artifact in understanding how this process of acceleration was initiated in the 1950s.

\section{The Seventies}

Around fifteen years after Contorno's launch and ten years after its demise, history had intensified. The legacy of the 1950s, the redefinition between art and politics, or more generally between ideas and action, had in the forefront of discussion and was permeating nearly all aspects of artistic and intellectual life. The midwives of history had multiplied and a new world was unquestionably imminent. All artistic spheres were producing new groups that viewed politics and art as different branches of the same tree.

127. Ibid., p. 8.

128. Term referring to the president Agustín P. Justo (1932-1938).

129. Ismael Viñas, "Orden y progreso," Contorno 9-10 (1959), p. 75

130. Among the circumstances accounting for the conclusion of Contorno, there is one fact that is perhaps not well known: the Contornistas attempted to undergo group psychoanalysis. Although a brief experiment, in 1959 some members of Contorno participated in a group therapy experience, during which they even took drugs, such as LSD, as part of the treatment conducted by the psychoanalyst Fontana. According to one of the participants, "we couldn't stand [the experience]." In any case, it is a sign of how seriously the group had taken a commitment to the political-intellectual attitude and the life experience it implied.

131. Ismael Viñas, “Orden y progreso," p. 75 
In the middle of the tumultuous year 1969, readers of Primera Plana, Argentina's most popular political magazine, were taken by surprise by somber news. The magazine's cover showed a painter's easel with a wreath of flowers, accompanied by the caption "Argentina: la muerte de la pintura." The editorial board commented that "the visual arts have suffered in the sixties their most profound upheaval." The article maintained that for an entire new generation, "for those under 45 years old [. . . ] not only are the visual arts dead but Art, in general, is something transitory." ${ }^{32}$ Not quite a year later, a women's magazine broached the theme of art with an article entitled, "El arte en crisis. ¿Muerte o transfiguración?" Luis Felipe Noé observed:

A definitive sign of change is the acceptance of art as a creative theory expressed in praxis. Art can no longer be defined as an aesthetic symbol transformed into a concrete object called 'a work of art'. I could expand much more [on this issue] pointing out the crisis in the art because of commodification, or the crisis of image-synthesis in a world populated by image-data that insert themselves in our private lives through television. The world around us grabs us by the lapels, invites us to join in and abandon any aesthetic sense. The only aesthetic possible today is the aesthetic of participating in change. ${ }^{133}$

In the same article, Gugú Lesca, a singer and ex-painter, argued that "the crisis does not just pertain to art. The crisis is total and absolute: the whole System is in trouble. There are no options. You are either against the system or you are in favor of it. I am against it." 134 For this artist, in a world in crisis, there was no option but for art to participate in and eventually overcome that crisis. In any case, both Noé and Lesca offer the impression that at this point in history, what is required of art is not frivolity but rather political engagement-a sentiment that echoes statements made fifteen years earlier in the pages of Contorno.

The various deaths announced during the seventies (i.e., the death of painting, of theater, etc.) could be reduced to one: the death of art. This was a way of refuting any politically disengaged artistic and intellectual modes of expression and at the same time calling for a greater involvement in social change. The "death of art" was not actually the death of all art but rather that of a certain way of conceiving of art, the death of art conceived as an independent, self-sufficient and apolitical sphere. In an article dedicated to visual art, one critic summarized that "in recent years some phrases like 'the death of art', 'art has lost its validity', or 'art ought to be compromised', form part of the lexicon of critics, artists, pseudo artists, and amateurs." 135 The article was dedicated to a group of visual artists called Grabas

132. Editorial, Primera Plana 333 (May, 1969), p. 1.

133. Ernesto Molina, "El arte en crisis. ¿Muerte o transfiguración?," Claudia 157 (June, 1970), p. 209.

134. Ibid.

135. "El certificado de validez," Panorama 329 (September, 1973), p. 50. 
that, in some sense, tried to swim against this current. In their reflections, they establish up to what point the relationship between art and politics was just common sense among the artists of the generation. "It is important for us to point out," affirmed Camporeale, one of the artists of Grabas, "especially now when this sanata about the death of art has become fashionable- the lack of use of the plastic art because of the political fact-that our more serious and deeper commitment is with art itself. That is our job: to be artists." 136 One of the colleagues in the group, Delia Cugat, noted that "the error of these assessments of art and politics lies in pretending that the artist starts from, a priori, a political premise." ${ }^{137}$ As we will see, within the world of art, Grabas was the exception, not the rule.

One prestigious theater critic of the 1970s, Ernesto Schoó, succinctly described the theatrical scene in those years. Commenting on a play by the group Libre Teatro Libre, originating in the Escuela de Artes at the University of Cordoba in the late 1960 s, he confessed that, "I was carrying a prejudice. I thought it was about one of those politically-charged denunciations, all too common in those last two years, full of false tortures, inflammatory dialogues and more enthusiasm than talent." ${ }^{38}$ This group, though more serious and talented than average, also participated in the world of actors and directors that viewed the theater as an almost exclusively political form of art. Libre Teatro Libre practiced "a theater conceived as a live political act, alert, and attentive to the concrete needs of a media." 139 As a matter of fact, one of its members defined the content of the group's wide range of works as "basically revolutionary."

A few months earlier, the brand-new Peronist government had named Juan Oscar Ponferrada, poet, playwright, and critic, head of the Teatro Municipal General San Martín, one of the largest and most important theaters of those years. According to this civil servant, a state cultural organism should be "a wide-open receptacle for the aesthetic suggestions and aesthetic concerns of the people. For that reason, the only requirement for an official theatre I conceive of is that it reaches out to attach itself to the people, intermingling with the people so that it becomes an echo chamber for the national voice." 140 In other words, the state should achieve a theater for the people, one that receives and reflects their own aesthetic values. By this time, the entire country was liable of being seen as a theater in which the protagonist, Juan Perón, did little more than interpret the

136. Ibid.

137. Ibid.

138. Ernesto Schóo, "Teatro: Ejercitaciones para la libertad. La alegría fundanental" Panorama 321 (June, 1973), p. 51 .

139. Ibid. p. 50 .

140. "Juan Oscar Ponferrada: Teatro nacional para una cultura nacional," Nuevo Confirmado 399 (August, 1973), 
desires of his people. "I don't think the theatre serves any other function at this moment than to identify itself with popular concerns. In other words, absorbing popular concerns and reflecting, in images, what the people intuit and believe they see in the future through the word of their leader and through their own sentiments, because it is the feelings of the people that the leader interprets." ${ }^{141}$ Many playwrights shared this vision and some of them, like Roberto Cossa, Humberto Riva, and Ricardo Monti, produced plays that were undeniably historical and politically engaged and that managed to be both instructive and revolutionary. The belief of the moment was that the theater was moving towards a new realism, in which "the realistic has to reflect [...] the process of very profound change"142 that the people were experiencing. For many intellectuals and artists of this time period, there was political theater or there was no theater at all.

Towards 1969, one novel caused an enormous debate within the relatively calm world of Argentine psychoanalysis. Heroina, written by the then-president of the Argentine Federation of Psychiatry, Emilio Rodrigué, raised the question of the social role of psychoanalysis. Somehow, the late 1960s and the first half of the 1970 s were marked by this desire to question the "social role" of every field in the intellectual world. Rodrigué's novel warned of the complicity between psychoanalysis and the status quo, inasmuch as it only served a privileged minority. He also pointed out therapists' lack of engagement with the national reality, and their empty promises, in a denunciatory tone that fit in with the attitude of the young people of Contorno. Three years after Rodrigué started this debate, a talented filmmaker named Raúl de la Torre adapted his novel for the cinema. While his book was being filmed, Rodrigué stated that "Heroina is a real odyssey of love whose intention is to assert the need to take a deep look inside yourself, the urgency of a full commitment to bring about change." 143 This was a few years after the emergence in Europe of Plataforma, a psychoanalytic movement that continued the work of Wilhelm Reich, concerning itself with the influence of the social system on patients. Its Argentine followers, the psychoanalysts Hernán Kesselman and Armando Bauleo, added an additional goal to the denouncement of the gentrification of analysis: "to give rise to the active intervention of psychoanalysis in the national politics." 144 "It is necessary that the popular masses have access to psychoanalysis," affirmed Bauleo, "something that hardly exists today." 145 The sexual barrier was displaced by the socio-economic. "Urgency demands other tasks such as the seizing of power by the people," 146 noted Bauleo,

143. Dicgo Baracchini, "Psicoanálisis de una heroína," Claudia 180 (May, 1972), p. 54.

144. "La industria del psicoanálisis: el marketing de la neurosis," Panorama 211 (May, 1971), p. 26.

145. Ibid., p. 27

146. Ibid. 
greatly politicizing a sphere that until recently was considered part of the pristine world of science.

The first half of the 1970s was marked by the idea that not only politics but everything (cinema, psychoanalysis, theater, literature, painting, and visual arts) should form part of the movement to radically transform society. Many have come to see this attitude as a reaction to the military dictatorship and to the political interdiction that followed Perón's fall from power in 1955. Nonetheless, as the Contorno case illustrates, this redefinition of the artistic sphere as essentially, possibly ontologically, political, had already taken place back in the 1950s, and its origins were to be found not in the fall of Perón but rather in his rise to power. Between the 1950 s and 1970s there was an expansion of a notion that once was limited to some small intellectual groups (including, but not exclusive to, Contorno) but which twenty years later constituted a sort of common sense for the times.

\section{Conclusion}

"From the fall of Perón to the rise of Frondizi we were contented," David Viñas pointed out in the journal Marcha on December 31, 1959. The article's title "La generación traicionada," can be considered Contorno's epilogue, though it was published in a different journal. Here Viñas defined his generation in the negative:

[T] he root of this generational attitude was a 'no'; 'no' to the Argentina of our elders that purposed to be presented as something without rifts and at worse with a bad odor; if we were anti-Peronists it was because we were 'anti-official'. 'No' to school, because our rebellion was, especially around 1945 , the rejection of anything to do with academics: false and idiotic discourse, stupid verses. 'No' to the anthologies full of dates, in a fine and flowery style and full of unbelievable and sacred words. 'No' to our country. 'No' to Argentina. 'No' to everything, absolutely everything. ${ }^{147}$

From the very beginning, the Contorno group knew what they did not want to be. Nevertheless, they encountered certain difficulties in determining with equal clarity what they did want to be. They did not want to become a new Martinfierrista generation; they did not want to be like Sur's "professionals of comprehension;" they did not want to share the bourgeois values of the acclaimed literature of the time; and they did not want to be a new intellectual elite. Neither did the Contornistas want to be Roberto Arlt or Ezequiel Martínez Estrada, writers whom they rescued amidst their fierce attack on their literary adversaries. As I have shown above, Arlt and Martínez Estrada were Contorno's weapons in the

147. David Viñas, "Una generación traicionada," p. 12. 
fight against its political adversaries. When Contorno's collaborators attacked, in the journal and outside it, Victoria Ocampo, Eduardo Mallea, or Jorge L. Borges, their aim, beyond criticizing the literature itself, was to target with their criticism what these writers, according to Contorno, symbolized: the liberal Pampeana and Europeanizing oligarchy and the middle and upper classes' bourgeois ideology.

During the 1950s, the aesthetic act came to be seen as essentially political, and cultural practices began to be subordinated to political objectives, thus initiating a process that would finally claim "the political" as a dimension encompassing all of social activity. Only ten years later it would be difficult to find leftist intellectuals who would not adhere to the maxim that "everything is politics." I have not proposed that Contorno provoked this perception but rather that in the pages of Contorno we find the clearest expressions of this ideological shift. Culture and politics confuse and merge themselves in a space in which it was not always possibleor, for many of its protagonists, desirable - to establish marked limits. This lack of limits was not a consequence of Contorno's appearance. On the contrary, Contorno was a consequence of it.

It was the Peronist experience, with all its implications in the cultural and social field, that pushed intellectuals into the political arena. "A whole generation, my generation," Sebreli wrote, "is irrevocably tied to Peronism forever. We can support or fight against it, cross our arms believing that it doesn't matter, but we can't dispense with it." ${ }^{48}$ Peronism had already become for Contorno the main dilemma to be resolved by leftist intellectuals, a dilemma that enjoyed a privileged place within the intellectual field during the following decades.

The figures of the organic intellectual and the revolutionary intellectual that would become more familiar in the following two decades found clear precedents in the committed intellectuals of the 1950s. Many Contornistas reached Marx through Sartre, and they all found in Existentialism an enormous potential to channel their critical passion. The need for a situated and engaged philosophy was one shared by all of Contorno's collaborators, no matter how dissimilar their points of view or interests. From Marx, the Contornistas saw Argentine society in class terms. To clean themselves of any remaining bourgeois ideas, they committed themselves to combating bourgeois consciousness and contributing to the leadership of the working class. They therefore supported and participated in Arturo Frondizi's political project. However, in pursuing these goals, they never let go of the supposedly enlightened superiority that, paradoxically, they were able to see in Sur but not in themselves. 
The Contornistas' resentment was the ink that flowed from their pens. Their intellectual rancor is obvious in several of their critiques of what they called "bourgeois literature." Their capacity to read in political terms these writers' works was the other side of the coin of their incapacity to read them from a literary perspective. ${ }^{149}$ The certainty that the political situation demanded the intellectual's voice and outlook, his engagement and his denunciation, led Contorno's main collaborators to shift, in the following decades, from the novel (which they imagined always entailed bourgeois passivity) to the political essay. ${ }^{150}$

Culture and politics tended, in the late 1960s and in the first half of the 1970s, to be indistinguishable categories. These decades would be marked by great social upheaval and the eruption of violence as a legitimate means of doing politics. This complete harmony between the world of action and the world of ideas was translated also, in some cases, in the exchange of the pen for the sword-or in the justification of its use in others' hands. The greater engagement between intellectuals and politics that I have proposed as a main feature of the 1950 s and specifically of the journal Contorno helps us to understand the beginning of this process.

\author{
Indiana University \\ Bloomington, Indiana
}

Sebastián CARAssai

149. Beatriz Sarlo has pointed out the following regarding Borges, "It is evident that Contorno couldn't read Borges." (Sarlo, "Los dos ojos de Contorno," p. 807.)

150. Rozitchner published Moral burguesa y revolución (1963), Ser judio (1967), Las Malvinas: de la gucrra "sucia" a la guerra "limpia" (1985) and Perón, entre la sangre y el tiempo (1985), anong other works; Sebreli published Martinez Estrada: una rebelión inútil (1960), Bucusos Aires: vida cotidiana y alienación (1964), Eva Perón: ¿aventurera o militante? (1966), Mar del Plata: cl ocio represivo (1970) and Los descos imaginarios del peronismo (1983), among other works; David Viñas published Literatura argentina y realidad politica (1964), Argentina: ejército y oligarquia (1967), Rebeliones populares argentinas: de los montoneros a los anarquistas (1971) and Qué es el fascismo en Latinoamérica (1977), among other works; Ismael Viñas published Orden y progreso: la era del frondizismo (1960), El radicalismo (1970), La reacción nacionalista (1971), Capitalismo, monopolios y dependencia (1972), and Tierra y clase obrera (1973); Pricto published La litcratura astobiográfica argentina (1962), El martinfierrismo (1967), and Estudios de literatura argentina (1969); Masotta published Sexo y traición en Roberto Arlt (1965), Conciencia y estructura (1969) and La bistorieta en al mundo moderno (1970); Kush published América profinda (1962), De la mala vida portcĩa (1966), Indios, porteños y dioses (1966) and El pensamiento indigena americano (1970), anong other works; Noé Jitrik published Leopoldo Lugones, mito nacional (1960), El escritor argentino: dependencia o libertad (1967) and Echeverria y la rcalidad nacional (1967). 